\title{
Pasar Kerajinan Tangan Dengan Pendekatan Arsitektur METAFORA Di KLATEN
}

Febrina Kusumandari, Bambang Triratma, Mohammad Asrori

Program Studi Arsitektur

Jurusan Arsitektur Fakultas Teknik

Universitas Sebelas Maret Surakarta

Email : febrinakusuma@ymail.com

\begin{abstract}
There are some reasons in building Handicraft Market in Klaten. The reasons are; there are so many handicraft potentials around Klaten, unavailable places which can provide all of the handicraft potentials in Klaten, and government's plan in developing facilities in Klaten. However, many young people start to leave and forget this heritage that should be protected. The problem that appears is how to design the facilities that can support and develop vacation industry in Klaten that consist of trading activity, giving information and promoting handicraft, and also recreation place. Therefore, it can make Klaten knowing by people. The method that is used in designing the market is architecture metaphor. The shape and meaning that is applied into the design is taken from Juwiring umbrella. The result is design of a Handicraft Market in Klaten which can provide place for trading activity, giving information and promoting handicraft, and recreation which its design and building adopts from Juwiring umbrella's shape. Juwiring umbrella is one of Klaten special handicrafts, so the expression of building reflects the activity inside the market. Then, Juwiring umbrella can preserve its existence and become Klaten's icon.
\end{abstract}

Keywords: Market, Handicraft, Architecture Metaphor, Juwiring umbrella

\section{PENDAHULUAN}

Indonesia dikenal sebagai negara penghasil kerajinan tangan yang beranekaragam dan berkualitas dengan harga yang bersaing. Saat ini barang kerajinan tangan banyak diminati oleh masyarakat lokal maupun internasional. Barang kerajinan tangan dari Indonesia sudah banyak diekspor keluar negeri. Klaten merupakan salah satu kabupaten yang ada di Jawa Tengah yang juga memiliki banyak potensi kerajinan, di antarnya adalah: batik kayu, batik tulis Bayat, tenun lurik Klaten, payung Juwiring, kerajinan keramik Melikan, ukiran kayu, cor besi, kerajinan tanduk, industri sulak, keset, sapu, tatah sungging (wayang), anyaman bambu. (Dinas Kebudayaan Pariwisata Pemuda dan Olah Raga Kabupaten Klaten).

Namun di Klaten saat ini belum ada fasilitas pusat perdagangan yang rekreatif yang mampu menampung para pengrajin untuk berjualan dan mempromosikan produknya di dalam satu tempat. Pemerintah Kabupaten Klaten tengah merencanakan untuk mengembangkan dan meningkatkan fasilitas di bidang perdagangan dan pariwisata berupa pasar kerajinan seperti yang dapat dilihat dalam Rencana Tata Wilayah Kota Klaten tahun 2009-2014. Akan tetapi generasi penerus saat ini sudah banyak yang mulai meninggalkan dan melupakan warisan budaya.

Permasalahan desain yang muncul yaitu bagaimana merancang fasilitas yang dapat mendukung dan mengembangkan pariwisata di Klaten yang di dalamnya terdapat kegiatan jual beli, informasi dan promosi serta rekreasi sehingga dapat memperkenalkan Klaten kepada khalayak ramai dengan menggunakan metode perancangan Arsitektur Metafora payung Juwiring.

Tujuan perencanaan dan perancangan pasar kerajinan tangan ini yaitu mendapatkan desain sebuah fasilitas yang dapat menampung kegiatan jual beli, informasi dan promosi serta rekreasi yang desain bangunannya mengadopsi dari bentuk payung Juwiring yang merupakan salah satu kerajinan khas Klaten, sehingga ekspresi bangunan dapat mencerminkan kegiatan yang diwadahi di dalamya serta sekaligus dapat melestarikan dan memperkenalkan kerajinan tangan Klaten, 
khususnya payung Juwiring sebagai ikon kota.

\section{METODE}

Metode pembahasan yang dilakukan untuk tahapan pembuatan konsep perencanaan dan perancangan Pasar Kerajinan Tangan di Klaten sebagai berikut.

\section{A. Penelusuran Masalah}

Tahap penelusuran masalah merupakan pemberangkatan ide awal untuk mengangkat tema/topik yang terpilih untuk penulisan konsep perencanaan dan perancangan Pasar Kerajinan Tangan di Klaten.

B. Pengumpulan Informasi dan Data

\section{Informasi}

Studi literatur merupakan tahapan mencari informasi melalui buku-buku referensi, situs-situs internet, atau hasil penelitian yang terkait dengan judulyang diajukan. Studi literatur tersebut terdiri dari
a.Potensi yang ada di Klaten (kerajinan tangan, pariwisata dan lain sebagainya).
b.Peraturan/kebijakan pemerintah tentang bangunan komersial dan pasar.
c.Peraturan daerah yang terangkum dalam RTRW Kabupaten Klaten.

\section{d.Arsitektur Metafora}

\section{Data}

a. Wawancara

Wawancara berupa pengumpulan data yang dibutuhkan untuk mengetahui informasi terkait informasi kegiatan, peruangan, lokasi melalui narasumber yang berkaitan.

b. Survey lapangan

Metode survey lapangan bertujuan mengetahui kondisi di lapangan. Selain itu survey lapangan juga digunakan untuk mengetahui kondisi fisik kawasan yang akan dijadikan tapak meliputi keadaan fisik-sosial kawasan, topografi, letak geografis, jaringan infrastruktur, serta potensi lingkungan sekitar lokasi perencanaan.

C. Analisis Pendekatan Konsep

Tahapan analisis dilakukan dengan analisis data menggunakan metode analisis deskriptif yaitu melalui penguraian data yang disertai gambar sebagai media berdasar pada teori normatif yang ada serta bagan-bagan alur.

D. Konsep Perencanaan dan Perancangan

Dari proses analisis secara arsitektural, akan dihasilkan beberapa konsep yaitu konsep lokasi dan tapak, konsep peruangan, konsep pengolahan tapak, konsep bentuk massa dan tampilan bangunan sebagai ekspresi Arsitektur Metafora, konsep struktur bangunan, dan konsep utilitas pada bangunan pasar kerajinan tangan di Klaten.

\section{ANALISIS}

\subsection{Analisis Manifestasi Konsep Metafora}

Pada Pasar Kerajinan Tangan di Klaten

Penerapan Arsitektur Metafora pada

Pasar Kerajinan Tangan di Klaten yang direncanakan akan diaplikasikan pada pengelolaan tapak, penataan ruang, pengelolaan massa dan pengelolaan struktur. Arsitektur Metafora yang diterapkan menggunakan combine metaphor atau penggabungan antara tangible dengan mengadopsi bentuk dari payung juwiring dan intangible metaphor yang mengadopsi dari makna payung Juwiring.

Payung merupakan alat pelindung badan supaya tidak terkena panas matahari atau hujan, biasanya dibuat dari kain atau kertas diberi tangkai dan dapat dilipat-lipat, dan ada juga yang dipakai sebagai tanda kebesaran (Kamus Besar Bahasa Indonesia. 2008).

Makna Payung Juwiring, merupakan payung hias yang terbuat dari bahan bambu dan kertas, selain berfungsi sebagai pelindung fisik payung juga bermakna sebagai pelindung secara psikologis yautu bermakna mengayomi, meneduhkan, menentramkan lahir dan batin serta melambangkan tanda kebesaran atau derajat seseorang di masyarakat.

Manifestasi metafora payung Juwiring pada pasar kerajinan tangan di Klaten yang direncanakan mengggunakan kata kunci yang terdapat dalam makna payung Juwiring dan ditransformasikan dalam wujud fisik meliputi proporsi, bukaan (transparansi), warna, tekstur dan bahan serta bentuk dan wujud bangunan. 
Tabel 1. Tabel Manifestasi Metafora Payung Juwiring pada Pasar Kerajinan Tangan di Klaten

\begin{tabular}{|c|c|c|c|c|c|c|c|}
\hline Aspek ORB & $\begin{array}{l}\text { Karakter Payung } \\
\text { Juwirimg }\end{array}$ & $\begin{array}{l}\text { Kata } \quad \text { Kalimat } \\
\text { Kunci }\end{array}$ & $\begin{array}{l}\text { Proporsi } \\
\text { komposisi }\end{array}$ & $\begin{array}{l}\text { Bukaani } \\
\text { Transparansi }\end{array}$ & Warma & \begin{tabular}{l|} 
Tekstur \\
$\&$ Bahan
\end{tabular} & $\begin{array}{l}\text { Bentuk \& } \\
\text { Wuiud }\end{array}$ \\
\hline $\begin{array}{l}\text { Pengelolaan } \\
\text { Tapalk } \\
\text { (Lansekap) }\end{array}$ & $\begin{array}{l}\text { 3.Pelindung } \\
\text { Fisik } \\
\text { 5. Mengayomi } \\
\text { 6.Meneduhkan }\end{array}$ & $\begin{array}{l}\text { - control } \\
\text {-pengaruh } \\
\text { negative } \\
\text { - fisik } \\
\text { - melindungi } \\
\text {-mengarahkan } \\
\text {-mendiddk } \\
\text { - menaungi } \\
\\
\text { - nyaman } \\
\text { - kondusif } \\
\text { - terlindungi } \\
\text { - barrier }\end{array}$ & $\begin{array}{l}\text { Akrab, } \\
\text { megah \& } \\
\text { terpusat' } \\
\text { memusat }\end{array}$ & $\begin{array}{l}\text {-respon } \\
\text { disesuaikan } \\
\text { dengan kondisi } \\
\text { site } \\
\text {-optimalisasi } \\
\text { penggunaan } \\
\text { vegetasi barier } \\
\text { pada arah } \\
\text { dengan noise } \\
\text { besar } \\
\text {-tidak massif } \\
\text { \& } \\
\text { memanfaatkan } \\
\text { alur udara } \\
\text { angin }\end{array}$ & $\begin{array}{l}\text { Menyes } \\
\text { uaikan. } \\
\text {-putih } \\
\text {-biru } \\
\text {-hijau } \\
\text {-coklat } \\
\text {-merah } \\
\text {-abu- } \\
\text { abu } \\
\text {-kuning }\end{array}$ & $\begin{array}{l}\text { Menyesu } \\
\text { aikan; } \\
\text { Halus, } \\
\text { kasar } \\
\text { berbahan } \\
: \\
\text {-vegetasi } \\
\text { halus dan } \\
\text { kasar } \\
\text {-batu } \\
\text { alam } \\
\text {-Beton } \\
\text {-Aspal } \\
\text {-keramik } \\
\text {-pasir } \\
\text {-dsb }\end{array}$ & $\begin{array}{l}\text { Lingkaran } \\
\text { menyesuai } \\
\text { kan }\end{array}$ \\
\hline Massa & $\begin{array}{l}\text { 1.Payung hias } \\
\text { 9.Derajat } \\
\text { seseorang di } \\
\text { masyarakat }\end{array}$ & $\begin{array}{l}\text { - memperindah } \\
\text { - mempercantik } \\
\text { - menghias } \\
\text { - strata/ } \\
\text { tingkatan } \\
\text { - berkehidupan } \\
\text { - klasifikasi } \\
\text { - budaya } \\
\text { - pertimbangan- } \\
\text { pertimbangan }\end{array}$ & $\begin{array}{l}\text { Akrab, } \\
\text { megah \& } \\
\text { terpusat' } \\
\text { memusat }\end{array}$ & $\begin{array}{l}\text { Disesuaikan } \\
\text { dengan fungsi } \\
\text { ruang dan } \\
\text { orientasi } \\
\text {-optimalisasi } \\
\text { pemanfaatan } \\
\text { pencahayaan }\end{array}$ & $\begin{array}{l}\text { Menyes } \\
\text { uaikan: } \\
\text {-putih } \\
\text {-biru } \\
\text {-merah } \\
\text {-oranye } \\
\text {-kuning }\end{array}$ & $\begin{array}{l}\text { Menyesu } \\
\text { aikan: } \\
\text { halus \& } \\
\text { kasar, } \\
\text { berbahan } \\
\text { beton, } \\
\text { batu }\end{array}$ & $\begin{array}{l}\text { Perpaduan } \\
\text { segitiga } \\
\text { dan } \\
\text { lingkaran } \\
\text { serta } \\
\text { penegasan } \\
\text { sudut }\end{array}$ \\
\hline
\end{tabular}

\begin{tabular}{|c|c|c|c|c|c|c|c|}
\hline & & - Mita & & $\begin{array}{l}\text { lea } \\
\text { resporia } \\
\text { tent }\end{array}$ & & $\begin{array}{l}\text { ban } \\
\text { beph } \\
\text { matil } \\
\text { bo }\end{array}$ & $180 \mathrm{gh}$ \\
\hline 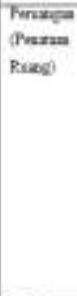 & 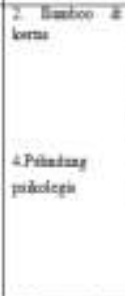 & 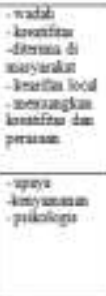 & 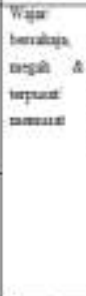 & 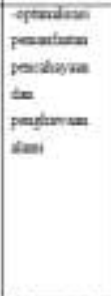 & 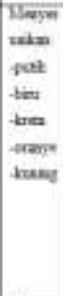 & 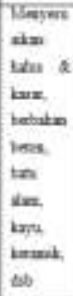 & $\begin{array}{l}\text { Prasgua } \\
\text { pat } \\
\text { thatama }\end{array}$ \\
\hline Sorvar & 1.Puiniany & 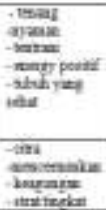 & $\begin{array}{l}\text { Mege } \\
\text { Mayesua } \\
\text { be }\end{array}$ & 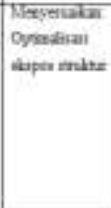 & 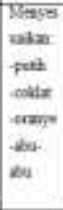 & 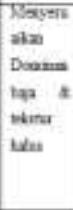 & 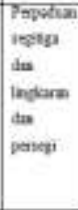 \\
\hline
\end{tabular}

\subsection{Analisis Tapak}

\subsubsection{Pemilihan Tapak}

Lokasi tapak terpilih berada di

Kecamatan Prambanan, Kabupaten

Klaten. Tepatnya berada di kawasan

Desa Kebondalem Kidul.

Potensi yang mendukung pemilihan

lokasi tapak terpilih antara lain:

1.Prambanan merupakan kecamatan yang berada diantara Solo-Jogja, sebagai gerbang masuk dan keluar.

2.Termasuk dalam wilayah pengembangan pariwisata.

3.Prambanan memiliki daya tarik wisata yang sudah terkenal hingga internasional.

4.Fasilitas transportasi yang ada stasiun kereta api, terminal angkutan umum.

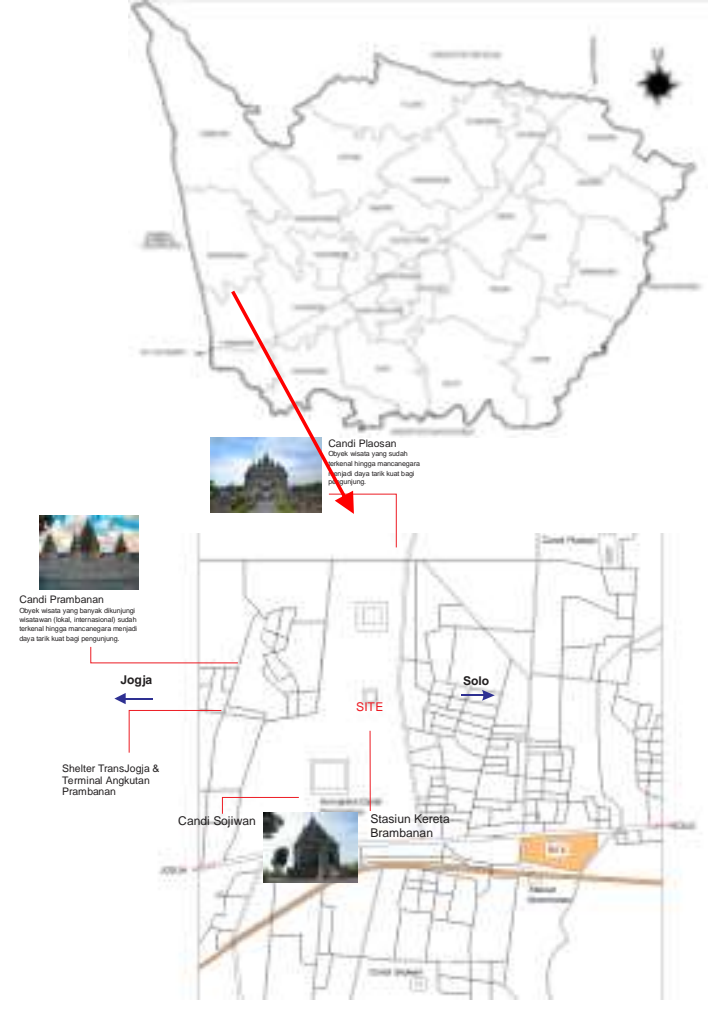

Gambar 1. Tapak Terpilih

Batas-batas tapak:

1. Utara : Jalan arteri primer SoloJogja, lebar jalan 20 meter dilalui 2 arah dan permukiman warga serta pertokoan.

2. Timur : Sungai kecil, persawahan, restoran.

3. Selatan : Rel kereta api, Stasiun Brambanan, persawahan.

4. Barat : Jalan lingkungan menuju stasiun kereta selebar 4-5 meter.

\subsubsection{Hirarki Tapak}

a. Tujuan:

Untuk mendapatkan pemintakatan tapak pada Pasar Kerajinan Tangan agar tidak terjadi overlapping antar zona yang satu dengan yang lain sehingga dapat terbentuk kesatuan fungsi yang harmonis antar zona atau fasilitas.

b.Dasar pertimbangan:

1.Jenis dan karakter kegiatan dalam kawasan pasar kerajinan tangan. 
2.Konsep perencanaan zonifikasi

3. Rancangan desain dan tata ruang denah

4.Pencapaian dan sirkulasi

5. Orientasi dan view tapak

6. Klimatologis

7. Vegetasi dan drainase

8. Kebisingan dan polusi

c. Proses:

Menggabungkan respon desain dari analisis-analisis yang berhubungan dengan tapak seperti pencapaian, orientasi dan view, klimatologis, vegetasi dan drainase serta kebisingan yang terjadi di dalam tapak.

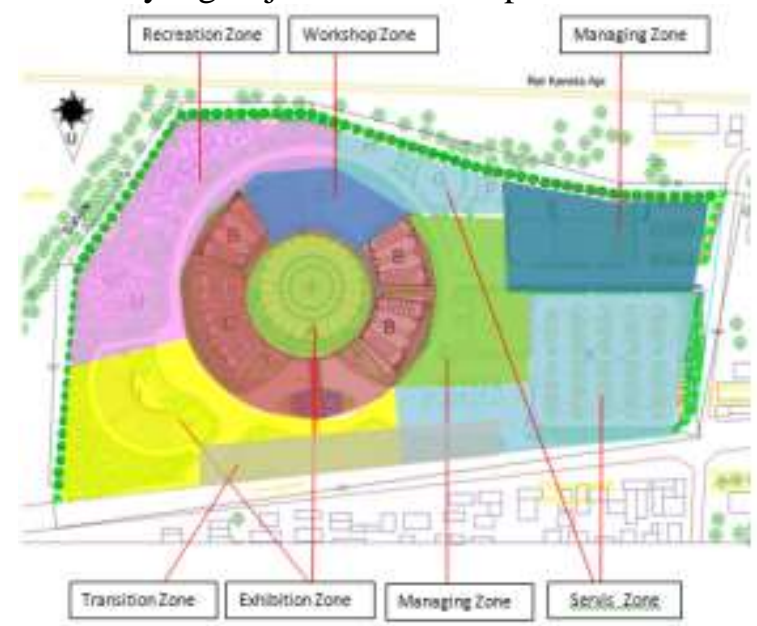

Gambar 2. Hirarki Tapak

\subsection{Analisis Peruangan}

\subsubsection{Jenis Kegiatan}

Jenis kegiatan yang diwadahi dalam Pasar Kerajinan Tangan di Klaten diantaranya adalah:

1. Kegiatan Jual-Beli

2. Kegiatan Promosi

3. Kegiatan Workshop

4. Kegiatan Rekreasi

5. Kegiatan Pengelola

6. Kegiatan Penunjang

7. Kegiatan Servis

\subsubsection{Analisis Kebutuhan dan Besaran Ruang}

Kebutuhan dan besaran ruang pada Pasar Kerajinan Tangan di Klaten adalah sebagai berikut:

- Kegiatan Jual-Beli

$$
=4215.36 \mathrm{~m} 2
$$

$\cdot$ Kegiatan Promosi

$$
=6021.8 \mathrm{~m} 2
$$

Kegiatan Workshop

$$
=2166.82 \mathrm{~m} 2
$$

- Kegiatan Rekreasi

$$
=1899.94 \mathrm{~m} 2
$$

-Kegiatan Pengelola

$$
=787.125 \mathrm{~m} 2
$$

-Kegiatan Penunjang

$$
=1063.2 \mathrm{~m} 2
$$

-Kegiatan Servis

$$
=6481.12 \mathrm{~m} 2
$$

TOTAL LUASAN $=22697.595 \mathrm{~m} 2$

\subsubsection{Hirarki Ruang}

Hirarki ruang menggabungkan antara kebutuhan ruang yang ada dengan kondisi dan analisis tapak yang telah dilakukan.

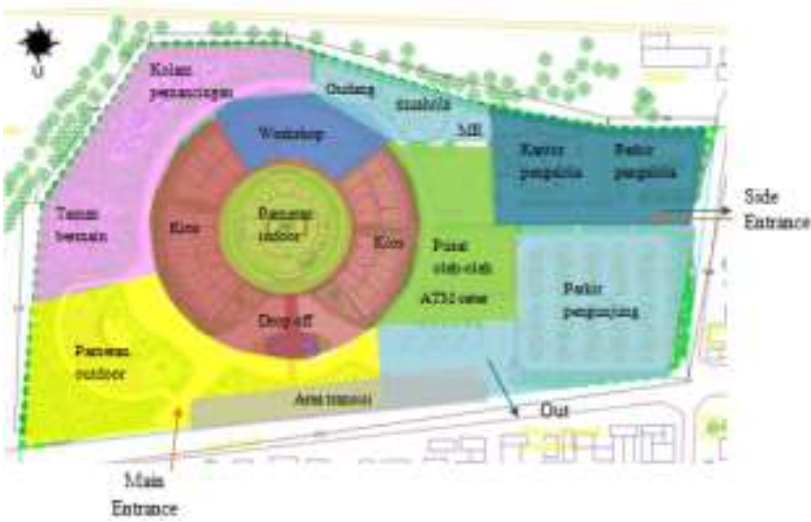

Gambar 3. Hirarki Ruang

\subsection{Analisis Bangunan}

Bentuk dasar bangunan Pasar Kerajinan Tangan mengadopsi dari bentuk dan makna Payung Juwiring yang kemudian ditransformasikan ke dalam bentuk bangunan.

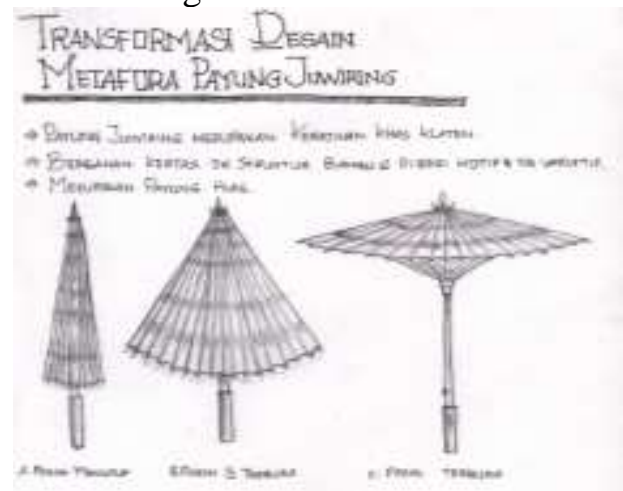

Gambar 4. Bentuk dasar payung Juwiring Mengambil dari 3 bentuk posisi payung tersebut kemudian digabungkan menjadi satu (menunjukkan pergerakan payung dari tertutup hingga terbuka) 
dan menghasilkan pola baru seperti di bawah ini:

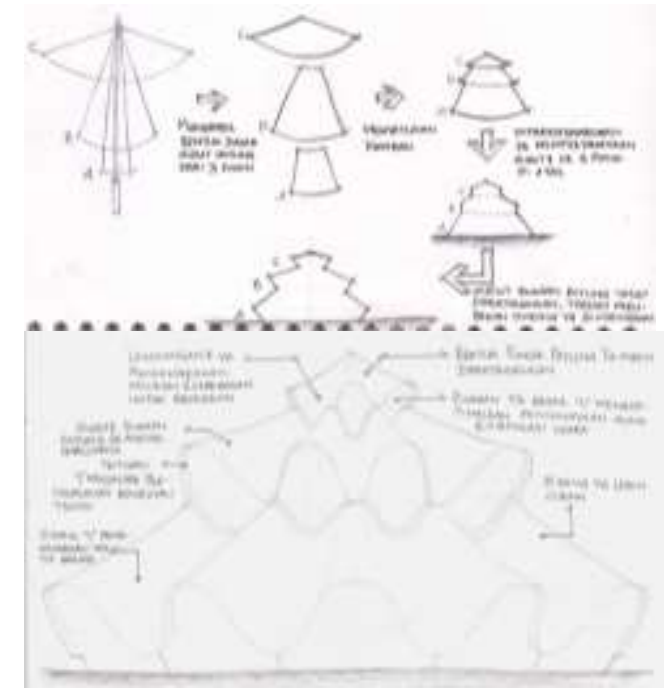

Gambar 5. Transformasi bentuk payung Juwiring

\subsection{Analisis Komplementer}

Pada perancangan desain Pasar Kerajinan tangan yang direncanakan struktur yang digunakan untuk bangunan utama khususnya adalah menggunakan sistem struktur shell/membran keras. Sistem struktur ini dipilih berdasarkan pertimbangan bentuk yang direncanakan yang mengadopsi bentuk payung Juwiring. Bentuk payung Juwiring yang dinamis berlekuk-lekuk memerlukan struktur dan bahan yang dapat mendukung bentuknya. Struktur shell menggunakan bahan:

1. Rangka menggunakan baja WF

2. Bahan penutup atap menggunakan logam metal/aluminium komposit $(\mathrm{ACP})$.

\section{KESIMPULAN}

Dari berbagai komponen yang telah di analisis, metafora payung Juwiring diterapkan pada empat aspek perancangan yaitu pada pengolahan tapak, penataan ruang, pengolahan massa, dan pengolahan struktur, sebagai berikut:

\subsection{Pengolahan Tapak}

Rencana tapak memiliki komposisi terpusat dengan pusat di tengah berupa bangunan pameran, sesuai dengan metafora yang digunakan yaitu payung Juwiring yang memiliki satu pusat (tongkat payung) berada di tengah.

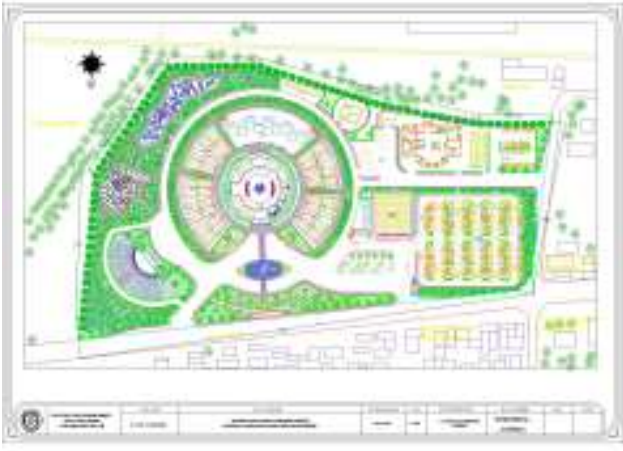

Gambar 6. Rencana Tapak

\subsection{Penataan Ruang}

\subsubsection{Perspektif Kios}

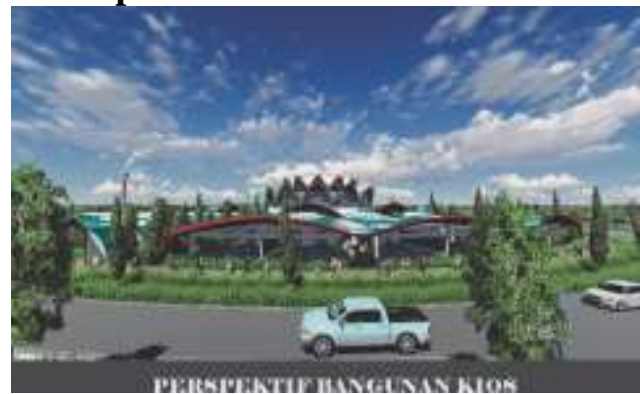

Gambar 7. Perspektif bangunan kios

Penataan ruang-ruang kios mengelilingi bangunan utama pameran. Bangunan kios ini merupakan perpanjangan dari bangunan utama yang diibaratkan perpanjangan dari bentuk payung Juwiring yang merupakan dasar bentuk metafora yang digunakan.

\subsubsection{Perspektif bangunan workshop}

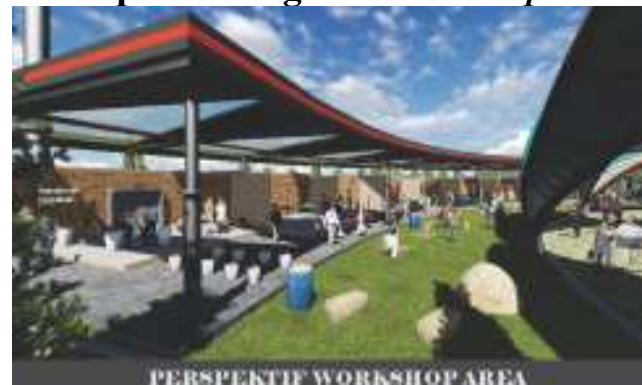

Gambar 8. Perspektif bangunan workshop Penataan ruang-ruang workshop mengelilingi bangunan utama pameran, sesuai dengan metafora payung Juwiring dengan komposisi terpusat. Fasilitas ini sebagai upaya untuk memperkenalkan dan melestarikan produk kerajinan tangan beserta cara atau proses pembuatannya. 


\subsection{Pengolahan Massa}

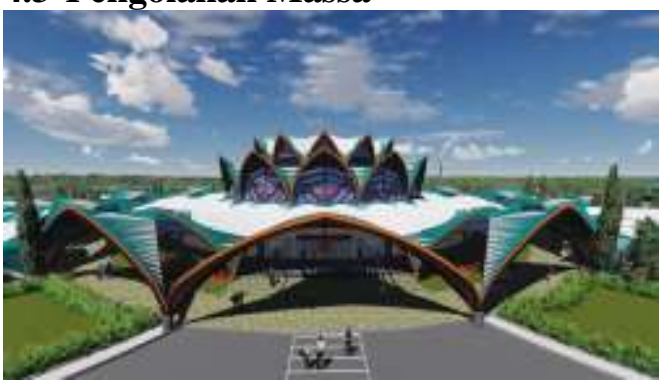

Gambar 9. Perspektif bangunan utama

Bentuk bangunan utama mengadopsi bentuk payung Juwiring yang memiliki 3 tingkat yang menunjukkan transformasi bentuk payung Juwiring yang menunjukkan 3 posisi payung (terbuka, setengah terbuka, terutup) dan sesuai dengan jumlah lantai yang ada di dalamnya.

\subsection{Pengolahan Struktur}

\subsubsection{Perspektif void bangunan utama}

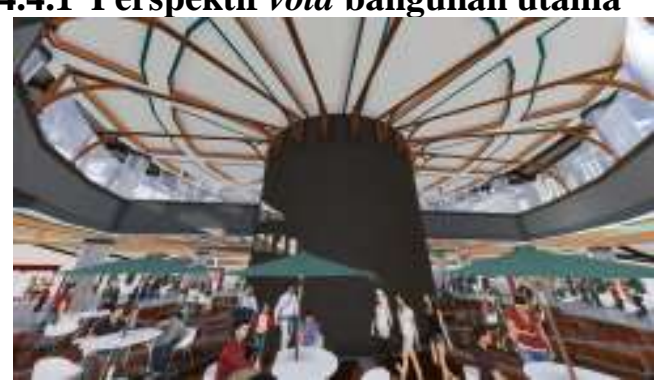

Gambar 10. Perspektif void

Langit-langit void bangunan utama yang berada di tengah bangunan utama mengadopsi dari payung Juwiring menunjukkan bagian rangka di dalam payung terlihat dari pengolahan plafon lantai 2/plat lantai 3 yang mengikuti bentuk balok lantai yang diperlihatkan lekuk-lekuknya sehingga terbentuk menyerupai jurai pada rangka payung dan dengan inti struktur berada di tengah diibaratkan batang payung.

\subsubsection{Perspektif ruang serbaguna}

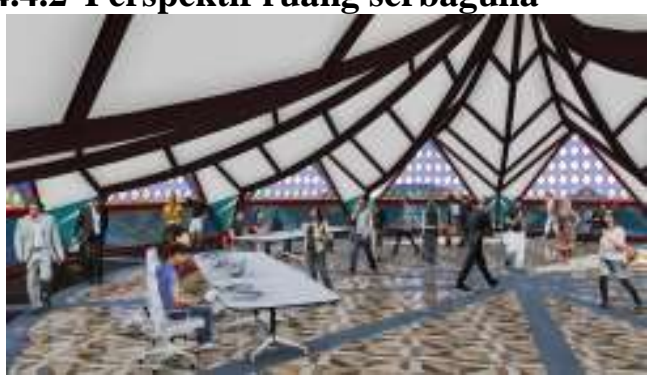

Gambar 11. Perspektif ruang serbaguna

Ruang serbaguna berada di lantai 3 bangunan utama. Pada langit-langit ruang serbaguna kerangka/struktur bangunan diperlihatkan sehingga memperlihatkan suatu bentuk yang menyerupai bagian di dalam payung.

\section{REFERENSI}

Kamus Besar Bahasa Indonesia. 2008. Departemen Pendidikan Nasional Republik Indonesia.

Katalaog Dinas Kebudayaan Pariwisata Pemuda dan Olah Raga Kabupaten Klaten. 